\title{
Land Ownership Constraints among Kuala Krai's Flood Victims: A conceptual framework
}

\author{
Thuraiya Mohd*, Mohamad Haizam Mohamed Saraf, \\ Siti Fairuz Che Pin, Tajul Edrus Nordin \\ Faculty of Architecture, Planning and Surveying, \\ Universiti Teknologi MARA, Malaysia \\ thura231@perak.uitm.edu.my
}

\begin{abstract}
Emphasis of this study is to investigate the land ownership constraints among the Kuala Krai flood victims. An empirical study was conducted at Jalan Geale B, C, C2, C3, C4 ad D along the Sungai Kelantan. A semi-structured interview was carried out to all the 128 owners or households by using purposive sampling to gauge their constraints in land ownership. The data was analysed using summative content analysis to quantify on particular words from text data, and interpretation of the text data result. The findings indicate that the main constraint faced by the flood victims without land ownership was financial.
\end{abstract}

Keywords: flood victims; land ownership constraints;

eISSN 2398-4279 @ 2018. The Authors. Published for AMER ABRA cE-Bs by e-International Publishing House, Ltd., UK. This is an open access article under the CC BY-NC-ND license (http://creativecommons.org/licenses/bync-nd/4.0/). Peer-review under responsibility of AMER (Association of Malaysian Environment-Behaviour Researchers), ABRA (Association of Behavioural Researchers on Asians) and cE-Bs (Centre for EnvironmentBehaviour Studies), Faculty of Architecture, Planning \& Surveying, Universiti Teknologi MARA, Malaysia.

DOI: https://doi.org/10.21834/ajqol.v3i12.147 


\subsection{Introduction}

Flooding happens to be the most frequent and significant natural disaster in Malaysia in term of population affected, event frequency, extent, duration and socio-economic damage especially in eastern coasts like Kelantan, Terengganu and Pahang (Department of Irrigation and Drainage [DID], 2007). Major floods in Kelantan in December 2014 were among the worst in the country's history (Kelantan Economic Planning Unit [EPU], 2015). Destruction in the area of Kuala Krai was terrible like a tsunami. More than 2,000 units of houses were destroyed in Kelantan as reported by the Kelantan Flood Disaster Committee. The highest number of destroyed house was in Kuala Krai with 1,850 houses, followed by Gua Musang (406), Machang (51), Tanah Merah (38), Kota Bharu (18) and Tumpat (11) (Kelantan Flood Disaster Committee, 2015).

Later after the flood disaster struck, the federal government has utilised the budget under the National Disaster Relief Fund, to provide 1, 255 units of new permanent houses for the flood victims who have lost their homes to the flood, while the remaining houses will be provided by the Kelantan state authority and other agencies (National Disaster Management Agency [NaDMA], 2015). The government expects the construction of the new permanent houses to be completed within a minimum period of 2 years. Still, as of the end of 2015, only 143 new permanent houses had been completed due to land ownership constraints. The procedure to build the new permanent house is the flood victims must show proof of land ownership (Salleh Buang, 2015).Obviously, these new permanent houses for them cannot be built on some other people's land, nor can they be built on state land with accordance to Section 206 (1) of the National Land Code (National Land Code 1965, p. 220). If the land title states clearly one's name as the registered proprietor, the issue of land ownership is generally no longer in dispute. The question arise is "what are the land ownership constraints face by the flood victims in Kuala Krai?". Motivated by the need to look into immediate action in the future and for justice to the flood victims without land ownership, this research attempts to explore the land ownership constraints face by the flood victims in Kuala Krai.

\section{Literature Review \\ Reviewing the Land Ownership Constraints}

There are several land ownership constraints that had been discussed from the previous studies. Land ownership itself may be missing (Adams and Hutchison, 2000; Salleh Buang, 2015). Missing title is among the constraints for providing evidence of land ownership. These often came to light during legal searches prior to conduct dealings such as sale or mortgage. This constraints might appear as a minor issue, however might resulting in delay of providing new permanent house for the flood victims.

Adams and Hutchison (2000) further added that ownership in dispute might also contribute to land ownership constraint. Disagreement between the land beneficiaries or trustees might be lengthening the ownership issues.In addition, Noordin et al (2012) found that unclaimed inheritances are accumulating because of low level of awareness on managing inheritance properties among the beneficiaries. This contributes to lengthy time and increasing cost in administration and distribution of inheritance problems that makes the 
beneficiaries find it difficult to settle. If the inheritance property is not claimed by the beneficiaries as provided under the Syariah law (faraid system), the land cannot be distributed to the right owner. This leads to dubious or unclear status of land ownership.

Another possible constraint related to beneficiaries' issues is unclaimed properties. According to Amanah Raya (2013), about MYR60 billion worth of unclaimed properties have not been transferred to the rightful owners because of the unidentified beneficiaries' issues. The procedure needed for the distribution of inheritance properties is that all beneficiaries must be identified before the distribution of properties can be made.

Multiple land ownership issue is another possible land ownership constraint from the existing literature (Samsudin Hitam, 1986; Azima Abdul Manaf et.al; Jasni Sulong and Marbawi Taha 2016). It was found that the implication of multiple land ownerships contributes to land ownership issues. The crisis among co-owners sometime prolong for generations, for example is the conflict between two families over compensation of land acquisition by the state authority that has spread to their children and grandchildren. This unsolved status of land ownership also leads to dubious status of land ownership.

Furthermore, United Nations Human Settlements Programme (2008) argued that affordability is one of the constraints to ownership. Most Asian cannot afford to make a dealing that is purchase of the property or land because their low income level is unqualified to obtain financial assistance from the financial institutions. Azima Abdul Manaf (2015) further added that financial issues might lead to the next constraint of land ownership, which is the phenomenon of squatter.

Above all, squatters or mere occupation of land without proper registration is the primary constraint in providing evidence of land ownership (Azlinor Sufian and Nor Asiah, 2009; Sharifah Zubaidah, 2011; Salleh Buang, 2015). A Squatter is a person who occupies somebody's land without owner's permission.

\subsection{Methodology}

The research instrument for data collection is semi-structured interview. This form of interview uses open and close-ended set of questions but the questions are not asked in a specific order or number. The characteristics of semi-structured interview or also called as a focused interview are it is focused on the respondents' experiences regarding the research topic and it takes place with respondents known to have been involved in a particular experience (Onwuegbuzie, A. J., Leech, N. L. and Collins, K. M., 2012). The locations chosen for semi-structure interview were at their current shelter to provide comfort and convenience to the flood victims. The duration of the session was between 5 to 10 minutes. Researchers wrote notes during the session as well as audio recording which later were transcribed.

The semi structured interview was conducted along the Sungai Kelantan which includes Jalan Geale B, Geale C, Geale C2, Geale C3, Geale C4 and Geale D.The respondents were selected by using purposive sampling technique. The total number of houses involved was 128 units and the semi-structured interview will be conducted to the 128 owners or household that could not provide land ownership as shown in Table 1. 
Table 1: Number of respondents according to th location

\begin{tabular}{c|c}
\hline Location & Number of respondents \\
\hline JALAN GEALE C & 24 \\
JALAN GEALE C2 & 31 \\
JALAN GEALE C3 & 7 \\
JALAN GEALE C4 & 32 \\
JALAN GEALE D & 34 \\
\hline TOTAL & $\mathbf{1 2 8}$ \\
\hline
\end{tabular}

(Source: Authors' Research)

For data analysis, the data from the semi-structured interview session will be analysed qualitatively by using contents analysis technique. In analysing the interview transcript, the data was conveyed and coded into distinct land ownership constraints and the similarities of the constraints will be classified or categorised. These coding were later illustrated into conceptual framework of classification of land ownership constraints.

\subsection{Results and Discussion}

In discovering the land ownership constraints, a successful semi-structured interview was conducted with 128 owners or households representing a response rate of $100 \%$. This empirical data revealed that 15 land ownership constraints were found and tabulated in Table 2.

Table 2: The land ownership constraints

\begin{tabular}{|c|c|c|c|c|}
\hline $\begin{array}{c}\text { Land Ownership } \\
\text { Constraints Classification }\end{array}$ & Code & Attributes & $\mathbf{N}$ & Total \\
\hline "Rumah suku-suku" & Code 1 & $\begin{array}{l}\text { Shared kitchen or toilet or } \\
\text { both }\end{array}$ & 3 & 3 \\
\hline Missing land title & Code 2 & Missing land title & 2 & 2 \\
\hline Multiple land ownership & Code 3 & Multiple land ownership & 5 & 5 \\
\hline Relocation & Code 4 & Safety & 4 & 4 \\
\hline Land physical condition & Code 5 & Land eroded & 1 & 1 \\
\hline \multirow{5}{*}{ Squatter } & Code 6 & Reserved (railway) & 21 & \multirow{5}{*}{31} \\
\hline & Code 7 & Reserved (burial ground) & 1 & \\
\hline & Code 8 & Reserved (mosque) & 2 & \\
\hline & Code 9 & Reserved (river) & 5 & \\
\hline & Code 10 & Private land & 2 & \\
\hline \multirow{2}{*}{ Ownership in dispute } & Code 11 & Beneficiaries issues & 4 & \multirow{2}{*}{16} \\
\hline & Code 12 & Inheritance issues & 12 & \\
\hline \multirow{2}{*}{ Financial } & Code 13 & Rent house & 54 & \multirow[b]{2}{*}{66} \\
\hline & Code 14 & $\begin{array}{l}\text { Rent land, tenant built } \\
\text { house }\end{array}$ & 11 & \\
\hline
\end{tabular}


Mohd, T., et.al. / Asian Journal of Quality of Life (AjQoL), 3(12) Jul / Aug 2018 (p.107-114)

\begin{tabular}{|l|c|l|c|c|}
\hline & Code 15 & Homeless & 1 & \\
\hline \multicolumn{2}{|c|}{ TOTAL } & \multicolumn{2}{|c|}{$\mathbf{1 2 8}$} \\
\hline
\end{tabular}

(Source: Authors' Research)

The first highlight from the semi-structured interview was "rumah suku-suku" (Code 1). The term "rumah suku-suku" was used by the local to exemplify a unit of house occupied by two families or more under a separate living and bedrooms but sharing the same kitchen, toilets or both. "Rumah suku-suku" has caused delay in providing new permanent house to all the affected families as the assessment only recorded one unit of destroyed house but the each family applies for the new permanent house. The government did not have immediate solution for this kind of constraint and nearly two years later, these flood victims are still living in the temporary shelter.

While the previous constraint was not having a land to build the NPH, there were two respondents with land received their new permanent house [NPH] behind the schedule because of the missing land titles (Code 2). The NPH only commence after they provide new land ownership to the contractor. This kind of delay should be solved immediately as the victims are the registered owner of the said land. This land ownership constraint should be handled immediately as this constraint was already discussed and reported by previous literature.

In regards to multiple land ownership (Code 3), five (5) respondents involved this type of land ownership constraint. Generally, several names are listed under the land title as registered proprietor. The delay occurs when each of the proprietors applied for NPH whereas the NPH is only given according to the number of destroyed house and not by the number of registered proprietors.

Another land ownership constraint is relocation (Code 4).There were four respondents who were relocated to a new area for safety. The new safe area was under construction as it involves more than 100 units of new permanent house, thus these four respondents need to wait until the completion of the resettlement construction.

Another highlight of land ownership constraints is the land physical condition (Code 5). The land was located on a hilly topography however the respondent's house was washed away by the major flood. After the flood, nearly half of his land was eroded and it is impossible to build NPH on that land. Thus, the government relocated him to a new safe area under the resettlement program in Telekong village.

Squatter is still prevalent in land ownership constraints. Although the government has requested them to move out in some cases, the squatters were still refused and some even claimed that they have proprietary interest over the land. From Table 5, most of the respondents ( $n=21$ ) were residing on reserved land for railway (Code 6$)$, followed by reserved land for river (Code 9) $(n=5)$, reserved land for mosque (Code 8$)(n=2)$, trespassing on a private land (Code 10) $(n=2)$ and reserved land for burial ground (Code 7$)(n=1)$. From the semi structured interview, it was found that most of the respondents had been residing on that land from generation to generation. Some cases, they were aware that the land belongs to the Tanah Melayu Railway (KTM). There are many reasons why they were squatting on reserved or private land, like economic, social or political factors. Looking at this issue, 
squatter needs to be addressed seriously and solve with a comprehensive approach from both government and private agencies.

In ownership in dispute, the disputes appear in beneficiaries (Code 11) and inheritance (Code 12) issues. In beneficiaries, the dispute between two brothers has led to delay in providing new permanent house for them. The respondent built a house on his father's land. After his father passed away, his brother became the beneficiaries of the land although his brother was living somewhere in Kuala Lumpur (a different state). After flood, knowing that the respondent will get NPH, his brother insisted to stay on that land, thus the respondent had to apply for Telekong resettlement program. The procedure to build the NPH is clear, the affected victims must show proof of ownership, otherwise the victims must seek help from the state government or NGO's to provide land for the construction of NPH.

Last but not the least is financial. Under this constraint, there are three attributes; Rent house (Code 13), Rent land, tenant built house (Code 14) and homeless (Code 15). It was recorded that the main land ownership constraints among the flood victims in Kelantan is Rent house $(n=54)$. Most of the victims do not have land ownership because they either rent the house or rent the land. From the semi-structured interview, it was also found that the respondents have financial issue to rent another house or to purchase land or housing. After the flood, even though they were promised for NPH, without land, the NPH cannot be built on someone else's land without permission otherwise they will be charged as trespassing.

These findings revealed that code 1 , code 4 , code 5 , code 6 , code 7 , code 8 , code 9 , code 10, code 13, code 14 and code 15 are the new empirical data. These attributes codes were analysed by using open coding analysis to develop a conceptual framework of land ownership constraints (see Figure 1)

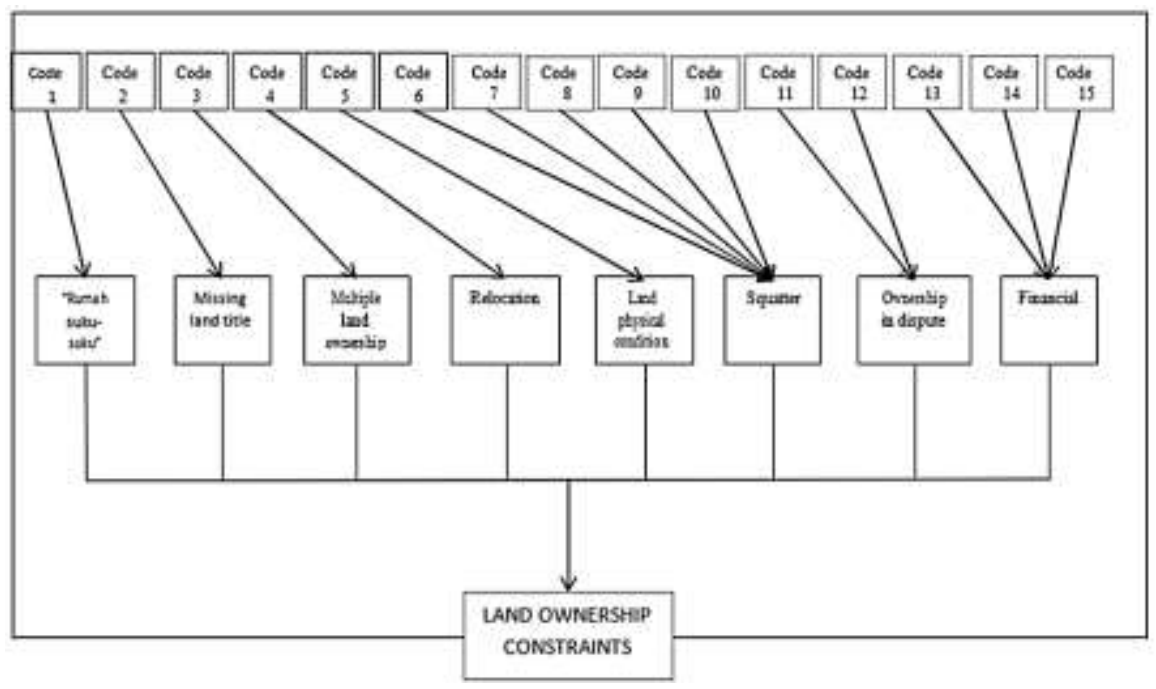

Figure 1: The Classification of land ownership constraints (Source: Authors' Research) 


\subsection{Conclusion}

The holistic approach in the Reconstruction and Rehabilitation phase that is to bring all the affected flood victims to their normal daily lives seems had overlooked the flood victims without land ownership who had lost homes and sources of livelihood. Two years later, many flood victims without land ownership are still living in temporary shelters that were intended to be used only for temporary basis, also leaving them at risk of eviction. Without land allocation for emergency, temporary shelters and new permanent houses, this flood victims without land ownership will have to continue staying in their transitional shelters while awaiting any NGOs to provide land for them.

\section{Acknowledgement}

The researchers would like to extend gratitude to Ministry of Finance for granting us funding under National Property Research Grant (NaPReC) to venture into this research and for unwaveringly supportive throughout the term of the research.

\section{References}

Adams, D., \& Hutchison, N. (2000). The Urban Task Force Report: Reviewing Land Ownership Constraints to Brownfield Redevelopment. Regional Studies; Nov 2000; 34, 8; ProQuest Dissertations \& Theses Global, 777-792.

Amanah Raya Berhad. (2013, November). Amanah Raya Berhad Online. Retrieved July 16, 2015, from Amanah Raya Berhad: $h$ ttp://www.arb.com.my/bm/berita/.View\&ID=291

Azima Abdul Manaf, Lyndon, N., Selvadurai, S., Mohd Yusof Hussain, Zaimah Ramli, Sarmila Md Sum, et al. (2015). Faktor Penghalang Pembangunan Tanah Rizab Melayu. Malaysian Journal of Society and Space 11 issue 8, 100109.F

Azlinor Sufian, \& Nor Asiah Mohamad. (2009). Squatters and Affordable Houses in Urban Area: Law and Policy in Malaysia.Theoretical and Empirical Researches in Urban Management (pp. 108-124). CCASP.

Burn, R. B. (1995). Introduction to Research Methods. Melbourne: Longman.

Chan, N. W. (2015). Challenges In Flood Disasters Management In Malaysia. International Water Resources Associations (IWRA) World Water Congress. Edinburgh: International Water Resources Associations and Scottish Government.

Department of Irrigation and Drainage. (2007). Flood and Drough Management in Malaysia. Kuala Lumpur: Ministry of Natural Resources and Environment.

Jasni Sulong, \& Marbawi Taha. (2016). Implications of Multiple Land Ownership in Malaysia. International Journal of Social Science and Humanity, Vol. 6, No. 5, 408-411.

Kelantan Economic Planning Unit. (2015). Pembangunan dan Pengurusan di Kawasan Terdedah Banjir. Kota Bharu: Kelantan State Government.

Kelantan Flood Disaster Committee. (2015). Laporan Implikasi Banjir Kelantan 2014. Kelantan: Kelantan Flood Disaster Committee. 
Merriem, S. B. (1998). Qualitative Research and Case Study Applications in Education (Second Edition). San Francisco: Jossey-Bass Publication.

Mohamad Haizam Mohamed Saraf and Thuraiya Mohd. (2015). Land Ownership Status Among the Flood Victims in Kuala Krai, Kelantan. International Real Estate Research Symposium (IRERS) 2016. Kuala Lumpur.

National Disaster Management Agency [NaDMA]. (2015). Disaster Portal. Retrieved June 13, 2015, from National Disaster Management Agency: http://portalbencana.ndcc.gov.my/Portal/Disaster

National Land Code. (n.d.). National Land Code 1965 (Act 56/1965). Petaling Jaya: International Law Book Services.

Noraini Noordin, Adibah Shuib, Mohamad Said Zainol, \& Mohamed Azam Mohamed Adil. (2012). Review on Issues and Challenges in Islamic Inheritance Distribution in Malaysia. International Journal of Sustainable Development, 27-38.

Onwuegbuzie, A, J.; Leech, N, L.; and Collins, K, M, T. (2012). Qualitative Analysis Techniques for the Review of the Literature. The Qualitative Report 2012 Volume 17, Article 56, 1-28. Nova Edu.

Salleh Buang. (2015, September 29). www.utusan.com.my. Retrieved December 16, 2015, from Utusan Online: http://www.utusan.com.my/rencana/selesai-segera-isu-hak-milik-tanah-1.140991\#sthash.zBh2K040.dpuf

Samsudin Hitam. (1986). Land Abandonment in Peninsular Malaysia: A Case Stuyd of The Malay Rubber Smallholders in the District of Ulu Selangor. The University of Wisconsin - Madison: University Microfilms International.

Sharifah Zubaidah. (2011). Eviction of Unlawful Occupiers of Land in Malaysia.

Retrieved June 23, 2015, from http://ssrn.com/abstract=2199758

United Nations Human Settlements Programme. (2008). Housing the Poor Guidelines. Bangkok: United Nations Economic and Social Commission for Asia and the Pacific (UNESCAP).

Yin, R. K. (1994). Case Study Research: Design and Methods (Second Edition). Thousand Oak, Calif: Sage. 